\title{
Atividade Antimicrobiana da Pectina do Noni (Morinda Citrifolia L.) Contra Bactérias de Origem Alimentar.
}

Elaine Cristina Pereira (I), Evânia Altina Teixeira De Figueiredo (I), Nágila Maria Pontes Silva Ricardo (I), Denilton Garcia Santos (I), Ana Carolina Barbosa Ribeiro (I), Arcelina Pacheco Cunha (I)

(I) UFC - Universidade Federal do Ceará (Av. Mister Hull, 2977- Campus do Pici - Bloco 858 CEP 60021-970 - Fortaleza/CE)

\section{Resumo}

A pectina é um polissacarídeo presente na parede celular dos vegetais, sendo constituída por unidades de ácidos D-galacturônicos. É amplamente empregada pelas indústrias alimentícias e apresenta diversas atividades biológicas como o efeito antibacteriano. Tendo em vista a necessidade de substâncias naturais com ação antimicrobiana para emprego em alimentos, a presente pesquisa objetivou extrair e avaliar a atividade antimicrobiana da pectina do noni (Morinda citrifolia L.) contra Salmonella Enteritidis IAL 1132 e Listeria monocytogenes ATCC 19115. A extração foi realizada com oxalato de amônio $0,25 \%$, a partir da polpa do noni maduro, na razão de 10:1 (solução extratora:massa da polpa), a $80^{\circ} \mathrm{C}$ por 2 horas sob agitação. O material extraído, após ser filtrado, foi precipitado com álcool etílico, dialisado por 5 dias e liofilizado. Determinou-se o rendimento e o grau de esterificação, através da espectroscopia de infravermelho (FTIR). Para avaliar a atividade antimicrobiana, empregou-se um método de microdiluição em caldo. Foram testadas as concentrações de 2000, 4000, 8000 e $10000 \mu \mathrm{g} / \mathrm{mL}$. Aos poços da microplaca, foram adicionados $120 \mu \mathrm{L}$ do caldo contendo $10^{5} \mathrm{UFC} / \mathrm{mL}$ da bactéria em estudo e $120 \mu \mathrm{L}$ da solução antimicrobiana padrão. Após o preparo das placas, fez-se a leitura da densidade óptica a $630 \mathrm{~nm}\left(\mathrm{DO}_{630}\right)$ usando um leitor de absorbância ELx808IU (BioTek Instruments, Inc., USA). As microplacas foram

\footnotetext{
Referência:

Elaine Cristina Pereira, Evânia Altina Teixeira De Figueiredo, Nágila Maria Pontes Silva Ricardo, Denilton Garcia Santos, Ana Carolina Barbosa Ribeiro, Arcelina Pacheco Cunha. Atividade Antimicrobiana da Pectina do Noni (Morinda Citrifolia L.) Contra Bactérias de Origem Alimentar.. In: Anais do 12 Congresso Latinoamericano de Microbiologia e Higiene de Alimentos - MICROAL 2014 [= Blucher Food Science Proceedings, num.1, vol.1]. São Paulo: Editora Blucher, 2014. 
incubadas a $35^{\circ} \mathrm{C}$ por 24 horas e, após esse período, uma nova leitura da $\mathrm{DO}_{630}$ foi realizada. Plaqueou-se $0,1 \mathrm{~mL}$ de cada poço da concentração $10000 \mu \mathrm{g} / \mathrm{mL}$ em ágar específico para cada micro-organismo. A extração apresentou um rendimento de $11,42 \%$, sendo a pectina obtida de baixo grau de esterificação. Verificou-se uma inibição de 82,98 \%, 67,58 \%, $28,04 \%$ e $37,52 \%$ para L. monocytogenes, nas concentrações de 10000, 8000,4000 e $2000 \mu \mathrm{g} / \mathrm{mL}$, respectivamente. Já para a S. Enteritidis, essa inibição foi de $86,17 \%, 70,97 \%, 29,08 \%$ e 7,52 \% nas mesmas concentrações, respectivamente. Conclui-se que a pectina do noni apresenta ação inibitória contra os patógenos estudados e que este efeito aumenta com uma maior concentração do polímero, sendo mais expressivo contra Salmonella Enteritidis. A ação bactericida não foi observada, necessitandose, provavelmente, de maiores concentrações desse polissacarídeo, acima do valor máximo testado.

Palavras-Chave: Atividade antimicrobiana, Noni, Pectina Agência de Fomento: 